\title{
FRANCO FERRAROTTI
}

\section{SOCIOLOGIA ALTERNATIVA}

\section{Ed. A. Redondo, Col. Beta, Barna, 1973}

F. Ferrarotti, en este libro, intenta redefinir la problemática social desde una perspectiva renovadora y sin convencionalismos. De este modo, coloca ante nosotros el objeto de la sociología en toda su profundidad: "La sociología crítica -nos dice-r es la ciencia que estudia, desde el punto de vista de la clase ascendente, la estructura de la sociedad con el objeto de transformarla racionalmente» (p. 7). Para el autor, la sociología que más aceptación tiene hoy en día en el mercado es la ciencia que la burguesía se ha apropiado para justificar -ideológicamente- su dominio sobre el proletariado. En este libro, pues, Ferratotti pretende -con acierto- presentarnos una alternativa» a esta apropiación, pero no desde una postura académica y formalista sino desde el punto de vista «de la acción directa de la clase obrera» (p. 52).

Con este ánimo, pasa revista a los problemas candentes que agitan la vida social -y la práctica sociológica-- desde los aspectos más sintomáticos y cotidianos (los accidentes de trabajo y su relación con la estructura productiva, el taylorismo, el absentismo laboral...) hasta los más estructurales y teóricos (la técnica, la polaridad burguesía-proletariado, las clases medias, la sociología urbana, el poder...).

Todos estos temas los trata con un agudo sentido crítico y los pone en relación con el sistema productivo.

Me parece que el gran valor que tiene este libro es su inmensa capacidad de suscitar polémica. Es una recopilación de escritos hábilmente arti- 
culados y sugestivamente expuestos. Pero la gran variedad de aspectos que esboza no lievan emparejada su resolución. Unicamente los descubre, se limita a dar pistas de investigación. Es un intento (ensayo) de redefinir problemáticas muchas veces mistificadas por los enormes intereses que juegan en su forma de tratarlos y, sobre todo, de resolverios.

Es un libro, en definitiva, de promesas y no de realidades en el sentido de que abarca mucho y aprieta poco. Pero no por esta razón es supetficial y vacio, puesto que descubre muchas ideas, sugiere muchas más y nos coloca en una perspectiva diferente de los enfoques que tradicionalmente se vienen adoptando.

Sintetizando mucho su contenido, puede decirse que es una crítica de la sociología tradicional y una alternativa para el desarrollo creativo de esta ciencia. $\mathrm{Y}$ en esto estriba su capacidad de acción.

FRANCISCO HERNANDEZ 